\title{
Occupational Stress among Nursing Officers in Selected Hospital of Sikar City (Rajasthan) with a View to Develop a Guideline on Stress Management
}

Prof. (Dr.) Mahipal Singh ${ }^{1 *}$, Nilesh Soni ${ }^{2}$

${ }^{1}$ Professor \& Principal Akhil Bharati Vidyapeeth College of Nursing, Sikar Rajasthan, India

${ }^{2}$ Assistant professor, Akhil Bharati Vidyapeeth College of Nursing, Sikar Rajasthan, India

DOI: $10.36347 /$ simcr.2020.v08i09.002

| Received: 18.08.2020 | Accepted: 28.08.2020 | Published: 02.09.2020

*Corresponding author: Prof. (Dr.) Mahipal Singh

Abstract

Original Research Article

Stress is frequently described as 'the black plague of the eighties or the modern epidemic' has become an important feature and major problem of everyday life, threatening individual, organization and societal health. It has also been found that different nurses experience job stress differently. Some studies reported that senior registered nurses and charge nurses experienced a higher degree of stress than other ranks of nurses. Hence a study was conducted to assess the Occupational Stress among nursing officers from the selected hospitals in Sikar city with a View to Develop a stress management protocol." A structured interview schedule was used to determine the Occupational Stress among nursing officers. Non Experimental descriptive design is used on 50 nursing officers from the selected hospitals in Sikar. The technique used in the study is Non probability convenient sampling technique and it shows that the overall mean stress score was found to be $39 \%$ in nursing officers. The mean stress score was found to be higher $64 \%$ in the aspect of safety and security, followed by $45.2 \%$ in work load, work organization and $35.2 \%$ in interpersonal relationship at work. Further, the less stress score (26.6\%) found in the area of preparation, skills and knowledge and $30 \%$ in working with patients and their family.

Keywords: Stress, Nursing Officers, Work Organization, Skills and Knowledge.

Copyright @ 2020: This is an open-access article distributed under the terms of the Creative Commons Attribution license which permits unrestricted use, distribution, and reproduction in any medium for non-commercial use (NonCommercial, or CC-BY-NC) provided the original author and source are credited.

\section{INTRODUCTION}

Stress is a physical or emotional state of response always present in a person as a result of living. It is intensified in a non-specific response to an internal or external environmental change or threat.

Job stress is a chronic disease caused by conditions in the work place that negatively affect an individual's performance and/or overall well-being of his body and mind, one or more of a host of physical and mental illnesses manifests job stress.

Large scale research suggests levels of occupational stress to be higher in the National Health Service than in other comparable professions. More than $28 \%$ of nurses suffer at least minor mental health problems. This compares with a figure of approximately $18 \%$ in the general employed population.

\section{Need for the study}

Nursing officers play an important role in the health team along with other health professionals. They strive for the prevention of disease, promotion of health and prolonging the life of individuals and the community. They work at patient level, doctor's level and administration level. In this setting, they face lot of physical and psychological stress.

However, Nursing officers during their clinical experience in a hospital set up or community set up have lot of 'work stress' due to work load, shift work, overtime etc. this Job stress and coping behaviors among nursing officers in the hospital units, provide information useful for nursing administrators to design programs to assist nursing staff or officers to deal with job stress. Even in any Programs to help nursing staffs to properly handle the difficulties generated by job pressures are needed to improve the quality of nursing care. 


\section{Problem statement}

Occupational Stress among Nursing Officers in Selected Hospital of Sikar City (Rajasthan) With a View to Develop a Guideline on Stress Management. Objectives of The Study: - is to assess occupational stress among staff nurses working in hospital and, to find the association between occupational stresses with selected demographic Variables and to develop a guideline on stress management.

\section{REVIEW OF LITERATURE}

Kulbe $\mathbf{J}$ [1] conducted a study on stressors and coping measures of hospice nurses. The nursing care of the dying patient in the home setting is considered highly stressful. As the population ages, the hospice census is expected to increase and the need to attract and retain hospice nurses will be vitally important.

Payne N [2] conducted a study on occupational stressors and coping as determinants of burnout in female hospice nurses. Results revealed that in general, the level of burnout (characterized by high emotional exhaustion, high depersonalization of patients and low personal accomplishment) was found to be low.

Pinikahana, Jaya [3] conducted a study on stress, burnout and job satisfaction in rural psychiatric nurses. This study presents the finding of a research study undertaken with rural psychiatric nurses $(n=136)$ in two rural mental health services in Victoria. The findings indicated that a low number of rural psychiatric nurses suffered from 'high' level of burnout and the majority of nurses reported, 'low level' of emotional exhaustion and depersonalization scores.

Sveinsdottir H, Biering P, Rame JA [4] conducted a study on occupational stress, job satisfaction and working environment among Icelandic nurses: A cross-sectional questionnaire survey. The study population was composed of all working nurses registered at the Icelandic Nurses' Association (INA). Approximately 95\% ( $\mathrm{N}=2234)$ of Icelandic nurses are members of the INA. The findings suggested that the strenuous conditions of Icelandic nurses are felt more severely among hospital nurses than among staff nurses working outside hospital settings.
Shen HC [5] conducted a study on occupational stress in nurse's psychiatric institutions in Taiwan. A cross-sectional study was conducted on 573 nurses, $17.2 \%$ of nurses reported being under significant stress often or always. Assault episodes were reported by $45.1 \%$ of nurses in the past 6 months. Among the nurses $16.9 \%, 25.2 \%, 50.0 \%$ and $7.8 \%$ belong to the "High Strain", "Low Strain", "Active" and "Passive" groups respectively perceived occupational stress was associated with young age, widowed/ divorced/ separated marital status, high psychological demand, low workplace support and threat of assault at work.

\section{Materials ANd Methods Research approach}

The main aim of this study is to assess occupational stress among nursing officers in selected hospital of Sikar city (Rajasthan) with a view to develop a guideline on stress management. The method adopted was descriptive survey approach. Research design adopted is non experimental uni-variant descriptive design in selected hospital of Sikar city. Study was conducted from nov 2018 to jan.2019 on 50 samples among nursing officers in selected hospital of of Sikar city. Samples were selected by non-probability purposive sampling technique.

\section{Description of the Tool Section I}

Demographic Data: This section of the tool consists of 18 items for obtaining information about the selected background factors of nursing officers.

\section{Section II}

Assessment of Stress:-standard selfadministered questionnaire to assess the level of stress among nursing officers consisting of 60 questions.

\section{DATA ANALYSIS \& RESULTS}

The collected data is tabulated, analyzed, organized and presented under the following headings: Section-I: Description of demographic characteristics of the sample

Section-II: Findings related to occupational stress among respondents 
Table-I: Distribution of Respondents According Demographic Characteristics

\begin{tabular}{|c|c|c|c|}
\hline \multirow{2}{*}{ Characteristics } & \multirow{2}{*}{ Category } & \multicolumn{2}{|c|}{ Respondents } \\
\hline & & Number & Percent \\
\hline \multirow{3}{*}{ Age (years) } & $27-35$ & 18 & 36.0 \\
\hline & $36-42$ & 19 & 38.0 \\
\hline & $43-50$ & 13 & 26.0 \\
\hline \multirow[b]{2}{*}{ Sex } & Male & 4 & 8.0 \\
\hline & Female & 46 & 92.0 \\
\hline \multirow[b]{3}{*}{ Religion } & Hindu & 34 & 68.0 \\
\hline & Christian & 13 & 26.0 \\
\hline & Muslim & 3 & 6.0 \\
\hline \multirow{2}{*}{$\begin{array}{l}\text { Professional } \\
\text { qualification }\end{array}$} & Diploma/GNM & 38 & 76.0 \\
\hline & Degree & 12 & 24.0 \\
\hline \multirow[b]{2}{*}{ Family size } & 2-3 members & 32 & 64.0 \\
\hline & 4-6 members & 18 & 36.0 \\
\hline \multirow[b]{2}{*}{ Type of family } & Nuclear & 38 & 76.0 \\
\hline & Joint & 12 & 24.0 \\
\hline \multirow{3}{*}{ Income per month } & Below Rs. 10,000 & 15 & 30.0 \\
\hline & Rs. $10,001-12,000$ & 23 & 46.0 \\
\hline & Above Rs. 12,000 & 12 & 24.0 \\
\hline \multirow[b]{3}{*}{ Total Experience } & Below 6 years & 15 & 30.0 \\
\hline & 6-15 years & 21 & 42.0 \\
\hline & Above 15 years & 14 & 28.0 \\
\hline
\end{tabular}

\section{Major Findings of Study}

\section{Section I: Analysis of the demographic data}

Distribution of the sample in age group revealed that majority (38\%) of respondents were in the age group of 36-42 years and majority were females $(92 \%)$.In relation to religion, majority $(68 \%)$ of them were Hindus. According to their professional qualification, $76 \%$ of them were Diploma/GNM and $24 \%$ were Graduates. Regarding family size, $64 \%$ had a family size of 2-3 members and 36\% had 4-6 members. In relation to type of family, majority $(76 \%)$ of them belong to nuclear family.

Income wise analysis shows that majority (46\%) of respondents had income between Rs. 10,00112,000 per month. In relation to experience majority (42\%) of the respondents had experience between 6-15 years.

Table-II: Distribution of Respondents According Demographic Characteristics

\begin{tabular}{|l|l|c|c|}
\hline \multirow{2}{*}{ Characteristics } & \multicolumn{2}{|c|}{ Category } & \multicolumn{2}{c|}{ Respondents } \\
\cline { 2 - 4 } & & Number & Percent \\
\hline \multirow{3}{*}{ Area of experience } & OT/EW/ICU/Casualty & 6 & 12.0 \\
\cline { 2 - 4 } & General ward & 3 & 6.0 \\
\cline { 2 - 4 } & Both & 41 & 82.0 \\
\hline \multirow{3}{*}{ Training undergone } & Intensive care & 9 & 18.0 \\
\cline { 2 - 4 } & Intensive neonatal & 3 & 6.0 \\
\cline { 2 - 4 } & Emergency nursing & 12 & 24.0 \\
\cline { 2 - 4 } & No & 26 & 52.0 \\
\hline Stress management & Attended & 6 & 12.0 \\
\hline programme & Not attended & 44 & 88.0 \\
\hline \multirow{2}{*}{ Marital status } & Single & 12 & 24.0 \\
\cline { 2 - 4 } & Married & 38 & 76.0 \\
\hline
\end{tabular}

\section{Major Findings Of Study}

Table II: Analysis of the demographic data :according to area of experience, majority (82\%) of have experience of both OT/EW/ICU/casualty and general ward. according to marital status, majority $(76 \%)$ of them were married. in relation to any type of stress management programme majority $(88 \%)$ don't have experience.

Section-II: Findings Related To Occupational Stress among Nursing Officers 
Table-III: Aspect wise Mean Stress Scores of Respondents

\begin{tabular}{|c|c|c|c|c|c|c|c|}
\hline \multirow{2}{*}{ No. } & \multirow{2}{*}{ Stress Aspects } & \multirow{2}{*}{$\begin{array}{l}\text { State } \\
\text { ments }\end{array}$} & \multirow{2}{*}{$\begin{array}{l}\text { Max } \\
\text { score }\end{array}$} & \multirow{2}{*}{$\begin{array}{r}\text { Range } \\
\text { score }\end{array}$} & \multicolumn{3}{|c|}{ Stress Score } \\
\hline & & & & & Mean & Mean $(\%)$ & SD (\%) \\
\hline $\mathbf{I}$ & Preparation, skills and knowledge & 10 & 40 & $2-20$ & 10.24 & 25.6 & 13.8 \\
\hline II & Work load and work organization & 10 & 40 & $8-28$ & 18.08 & 45.2 & 15.1 \\
\hline III & Interpersonal relationship at work & 10 & 40 & $2-28$ & 14.08 & 35.2 & 15.7 \\
\hline IV & Uncertainty in working environment & 10 & 40 & $6-26$ & 13.58 & 34.0 & 15.7 \\
\hline $\mathbf{V}$ & Working with patients and family & 10 & 40 & $3-28$ & 12.00 & 30.0 & 18.1 \\
\hline VI & Safety and security & 10 & 40 & $11-38$ & 25.58 & 64.0 & 19.2 \\
\hline & Combined & 60 & 240 & $48-154$ & 93.56 & 39.0 & 13.2 \\
\hline
\end{tabular}

\section{Major Findings of Study}

Table III: Findings Related to Occupational Stress:-The findings revealed that overall mean stress score was $39.0 \%$. The highest mean percent of stress score $(64.0 \%)$ noticed in safety and security domain and lowest mean percent score $(25.6 \%)$ was in preparation, skills and knowledge domain. In work load and work organization, respondents mean stress was $45.2 \%$ whereas in interpersonal relationship at work domain the respondents mean stress was $32.2 \%$. In the area of uncertainty in the working environment, the mean percentage of stress among the respondents was $34.0 \%$ and in working with patients and family area was $30.0 \%$.

Table-IV: Distribution of Respondents According To Level of Stress

\begin{tabular}{|c|c|c|}
\hline \multirow{2}{*}{ Stress Level } & \multicolumn{2}{|c|}{ Respondents } \\
\cline { 2 - 3 } & Number & Percent \\
\hline Low (<50\%) & 34 & 68.0 \\
\hline Moderate (51-75\%) & 16 & 32.0 \\
\hline Combined & 50 & 100.0 \\
\hline
\end{tabular}

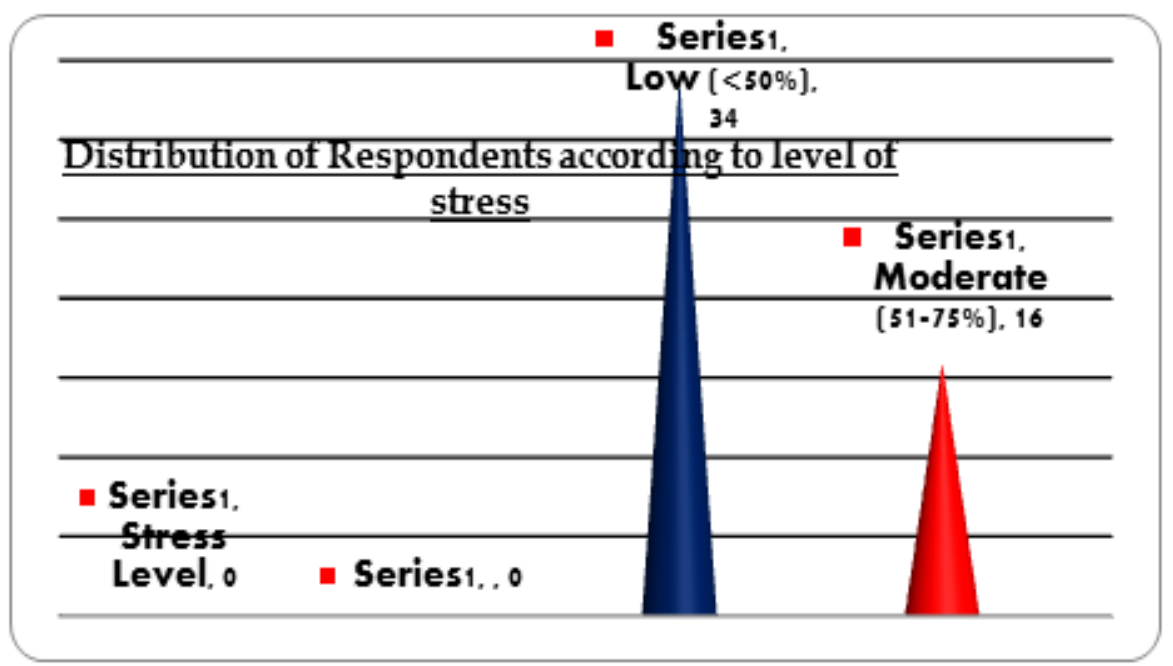

Fig-1: Cone Diagram Showing Distribution of Respondents According to Level of Stress

\section{Major Findings of Study}

Table IV: Findings Related to Level of Stress:Reveals the distribution of respondents by stress level (low and moderate) the result indicates that $68 \%$ of respondents had low stress level as compared to $32 \%$ moderate stress.

\section{Conclusion}

Major finding of the study reveals that the mean stress score was found to be $39 \%$ in nursing officers. The mean stress score was found to be higher $64 \%$ in the aspect of safety and security, followed by $45.2 \%$ in work load, work organization and $35.2 \%$ in interpersonal relationship at work. Further, the less stress score $(26.6 \%)$ found in the area of preparation, skills and knowledge and 30\% in working with patients and their family. Prolonged stress might lead to ill health by altering various systems of the body like nervous, immune or endocrine system leads to modification in heart rate, blood pressure and other activities of the organs. Finally Stress Management Guideline was developed to deal with prolonged level of stress.

\section{REFERENCES}

1. Hagemann T, Wilson J, Burke F, Kulbe H, Li NF, Plüddemann A, Charles K, Gordon S, Balkwill FR. Ovarian cancer cells polarize macrophages toward a tumor-associated phenotype. The Journal of Immunology. 2006 Apr 15;176(8):5023-32.

2. Payne N, Jones F, Harris PR. The impact of job strain on the predictive validity of the theory of 
planned behaviour: An investigation of exercise and healthy eating. British Journal of Health Psychology. 2005 Feb;10(1):115-31.

3. Pinikahana, Jaya. Stress, burnout and job satisfaction in rural psychiatric nurses - Victorian study. Austl J Rural Health. 2004 Jun; 12(3): 120125 .
4. Sveinsdottir H, Biering P, Rame JA. Occupational stress, job satisfaction and working environment among Icelandic nurses: A cross-sectional questionnaire survey. Int J Nurs Stud. 2005 Dec 14; 17: 43-57.

5. ShenHC.Occupational stress in psychiatric institutions in Taiwan. J Occupational Health. 2005 May; 47(3): 218-225. 